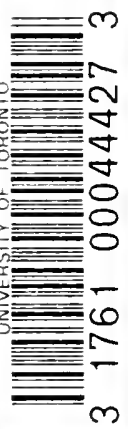

PASC

$T P$
326
$C 3 N T 3$

1885 


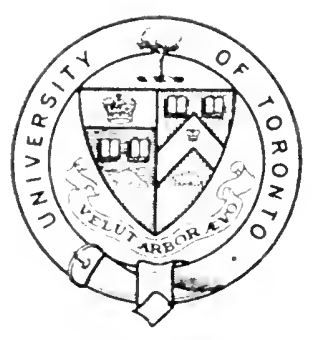

F.Tresutris ta

The thilnatre uff the

Aluimersity of Torouto

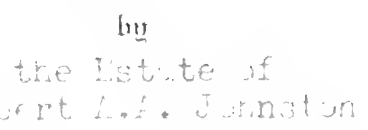


GEOLOGICAL AND NATURAL HISTORY SURVEY OF CANADA

ALFRED R. C. SELWYN, LL.D., F.R.S., F.G.S., Director.

\section{CHEMICAL CONTRIBUTIONS}

TO THE

\section{GEOLOGY

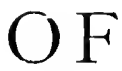 \\ CAN A D A,}

FROM THE

LABORATORY OF THE SURVEY.

BY

G. CHRISTIAN HOFFMANN, F. Inst. Chem., Chemist and Mineralogist to the Survey.

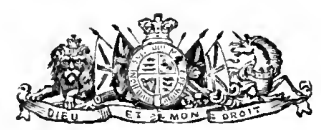

PUBLISHED BY AUTHORITY OF PARLIAMENT.

MON'TREAL :

DA WSON BROTHERS.

1885 . 


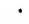




\section{GEOLOGY OF CANADA,}

FROM THE

LABORATORY OF THE SURVEY.

BY

G. CHRISTIAN HOFFMANN, F. Inst. Chem., Chemist and Mineralogist to the Survey.

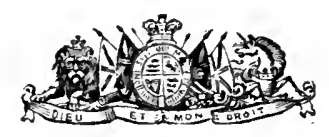

PUBLISHED BY AUTHORITY OF PARLIAMENT.

MONTREAL :

DAWSON BROTHERS. 1885. 

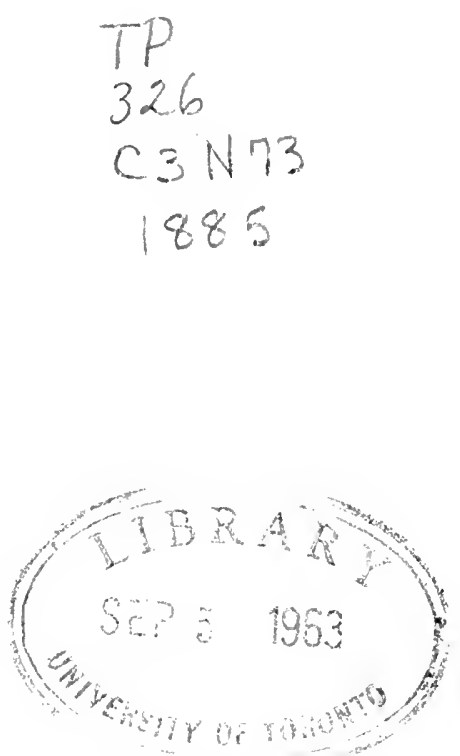

857875 
Alfred R. C. Selwyn, Esq., LL.D., F.R.S., F.G.S.,

Director of the Geological and Natural History Survey of Canada.

SrR,-I beg to present herewith my report upon the work carried out in the Laboratory of the Survey during the year ending August 31,1885 . It embraces only such analyses and examinations as were considered likely to prove of general interest. As will be seen, attention has been mainly directed to the examination of such minerals, etc., etc., as were deemed likely to prove of economic value.

Of the work here recorded, Analyses 3, 4, 5, 6, and 8-Assays 6 to 13 inclusive, and Examination 2, under Miscellaneous Minerals, were conducted by Assistant Chemist, Mr. Frank D. Adams.

I have the honor to be,

Sir,

Your obedient servant,

G. CHRISTIAN HOFFMANN.

Ot'tawa, August 31, 1885. 


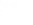




\section{TABLE OF CONTENTS.}

(M.)

I'AGE.

Coald and Ligntres.

I.-Lignites, Analyses of, from-

South Saskatchewan, north bank, seven miles west of Medicine

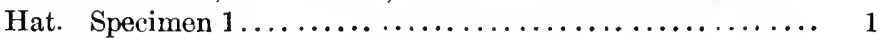

South Saskatchewan, north bank, seven miles west of Medicine

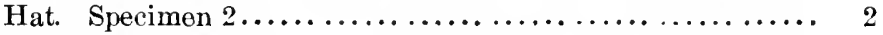

Hay Flat, Wood Mountain, ten and a-half miles east of Wood Mountain Post............................... 3

Shaft on bank of Crowfoot Creek, ahout five miles from its entry into Bow River .............................. \&

Willow Creek, six miles south-east of head of monntain, Cypress Hills.

II.-Lignitic Coal, Analysis of, from-

Nortl edge of Milk River Ridge, one and a-half mile east of Fossil

Coulée

III.-Conls, Analyses of, fron-

Crow Nest Pass, Rocky Mountains...................... 6

Red Deer River, Rocky Mountains................... 7

South Fork of the Old Man River, four miles above the south branch, Rocky Mountains ........................ 7

Oyster Creek, north-west branch, North Fork, Old Man River .... 8

North-west branch of the North Fork, Old Man River, Rocky

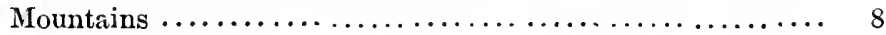

Second crossing, Martin Creek, Rocky Mountains, British Columbia $\ldots \ldots \ldots \ldots \ldots \ldots \ldots \ldots \ldots \ldots \ldots \ldots \ldots, \quad 9$

Semi-Anthracite, Analyses of, from-

Bow River, right bank, about one and a-half mile from Canmore

Station, Rocky Mountains........................ 10

Cascade River, near Bow River, Rocky Mountains............ 10 
Natural Waters.

Water from a spring near River Beaudette, seigniory of Longeuil, Soulanges County, P. Que., analysis of............... 12

Saline water from an artesian well at Rosenfeld Station, Manitoba,

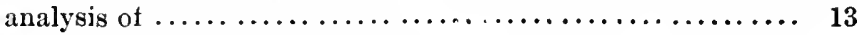

Water from a spring at Halowell Grant, Antigonish, Antigonish County, Nova Scotia, analysis of .................. 15

Water from Silver Islet mine, Lake Superior, Ontario, analysis of. . 17

IroN OREs.

Magnetite from vicinity of Port Digby, Digby County, Nova Scotia,

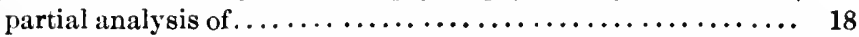

Magnetite from Bagot, Renfrew County, Ontario, partial analysis of 18 COPPER ORES.

Copper ore from the township of McKim, District of Nipissing, Ontario, partial analysis of $\ldots \ldots \ldots \ldots \ldots \ldots \ldots \ldots \ldots \ldots$

Manganese Ores.

Psilomelane from Gowland Mountain, Elgin, Albert County, New Brunswick, partial analysis of $\ldots \ldots \ldots \ldots \ldots \ldots \ldots \ldots$.

Gold and Silver Assays.

Of specimens from the-

Province of New Brunswick $\ldots \ldots \ldots \ldots \ldots \ldots \ldots \ldots \ldots \ldots, 20$

" Ontario............................ 21

North-west Territory $\ldots \ldots \ldots \ldots \ldots \ldots \ldots \ldots \ldots \ldots \ldots \ldots, 23$

Province of British Columbia ..................... 24

Miscellaneous Minerals.

Galenite-From Silver Islet, Lake Superior, Ontario ...........

Witherite-From Twin City mine, Thunder Bay, Lake Superior,

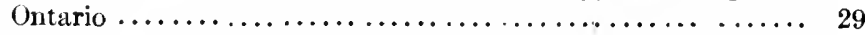
Molybdenite-From the townslip of Aldfield, Pontiac County, P. 


\section{CHEMICAL CONTRIBUTIONS}

TO THE

\section{GEOLOGY OF CANADA,}

FROM THE

\section{LABORATORY OF THE SURVEY.}

BY

G. CHRISTIAN HOFFMANN, F. Inst. Chem.,

Chemist and Mineralogist to the Survey.

\section{COALS AND LIGNITES.}

[In continuation of the previous report on this subject, Report of Progress, 1882-83-84,-Report MI.]

The fuels in question are, with the exception of No. 49, all from the North-West Territory.

38.-Lignite.-From the Saskatchewan Coal Mining and Transportation Company's mine (from what part of the workings could not the South be ascertained), South Saskatchewan, north bank, seven miles west of Medicine Hat. Main seam. Seam abont five feet thick. Geological position-Cretaceous, Belly River series. Received from D. B. Woodworth, Esq., M.P.

Structure somewhat coarse lamellar-moderately compact; with the exception of one layer it presented throughout a general appearance of great uniformity alike in texture, color, and lustre; it contains an occasional interstratified layer of mineral charcoal, likewise thin plates of gypsum and numerous minute crystalline aggregations of pyrite; it has also a large amount of a lemonyellow, occasionally brownish-yellow, sub-transparent to transparent resin, chiefly in small particles, difficed through its substance; color greyish-black; lustre resinous; fracture uneven; apart from the layers of mineral charcoal, does not soil the 
Lignite from the South Saskatehewan, [continued.]

Analyses of.

Lignite from the South Saskatchewan. fingers; powder black, with a slight brownish tinge; it communicates a deep brownish-red color to a boiling solution of causticpotash. The layer referred to above, as differing in general appearanee from the rest of the specimen, averaged, in one fragment weighing fifteen pounds, seven-eighths of an inch in thickness; the material composing it was very compact, exhibited, although but faintly, a delicate ligneous structure, had a black color, a resinous lustre, and a conchoidal fiacture. This band was coated on either side by a moderately thick, firmly attached, layer of mineral chareoal. It would appear to consist of the more solid portion-trunk or branch-of some of the vegetable matter from which the bed of lignite has been derived. This lignite when first received was tolerably hard and firm, and remained so for some little time; on further exposure to the atmosphere, however, it became more or less fissured, and hence somewhat tender.

Analyses by slow and fast coling gave:

Slow coking. Fast coking.

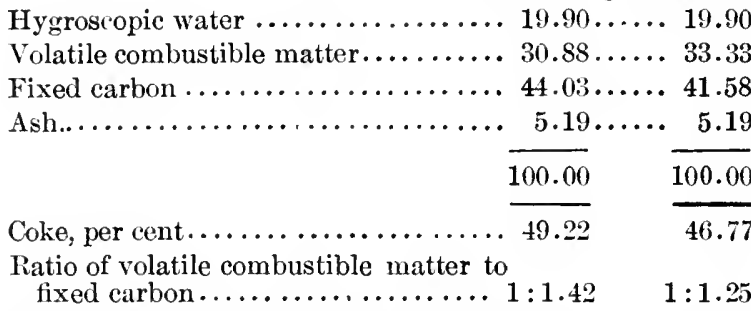

It yields-both by slow and fast coking, a non-coherent coke; the gases evolved during coking burnt with a yellowish, slightly luminous, almost smokeless flame. The ash has a brownish-yellow color,-at a bright red heat it becomes slightly agglutinated, at a: most intense red heat it becomes fritted.

39.-Lignite.-Subsequent to the examination of the preceding specimen, another sample of the lignite from this mine was received for analysis. This sample was taken from No. 6 level, three hundred and twenty feet from the entrance. It was accompanied by a statement to this effect-" The coal in all the levels at this mine is pretty much of the same character; in the upper part of the seam is a band of coal a few inches thick, like Parrot coal. I send specimens of this with the other."

The material constituting what is here referred to as a band in the upper part of the seam, differed somewhat in character; one portion fully answered to the description given of the layer alluded to when describing the previous specimen, as differing in 
general appearance from the rest of that specimen, the remainder exhibited, although somewhat indistinctly, a very fine lamellar structure, was compact, had a greyish-black color, a resinous lustre, and an uneven, occasionally imperfectly conchoidal, fracture.

The description given of the preceding specimen and the remarks made in regard to it, apply also to this specimen, which, as will be seen, also differed from it but very slightly in composition.

Analyses by slow and fast coking gave:

Analyses of.

Slow coking. Fast coking.

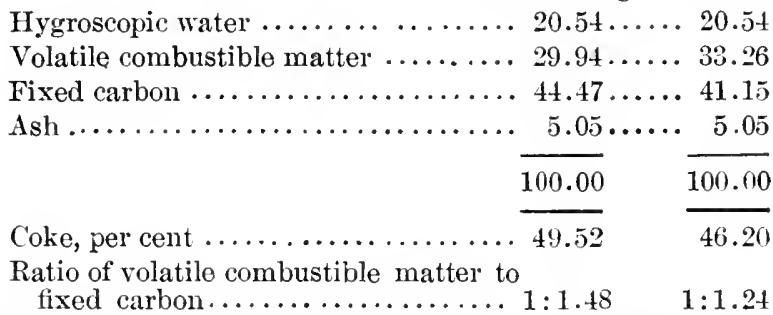

The claracter of the coke, color of the ash, and behaviour of the latter at elevated temperatures, was the same as that of the preceding specimen.

40.-Lignite.-From Hay Flat, Wood Mountain, ten and a-half miles east of Wood Mountain Post. Seam six feet thick. Geological Way Wlat,
position-Laramie. Collected by Mr. R. G. McConnell.

Structure, for the most part, moderately fine lamellar, it contains, howerer, an occasional somewhat thick, irregular shaped layer of dense material, also, and more immediately associated with the latter, a few thin seams of a dull chocolate-brown colored substance-tolerably compact; color greyish-black; lustre subresinous; fracture uneven; the dense material has a pure black color, a resinous to vitreous lustre, and a more or less conchoidal fracture; does not soil the fingers; powder dark brown, inclining to brownish-black; it communicates a deep brownish-red color to a boiling solution of caustic potash; by exposure to the air becomes somewhat fissured and hence tender.

Analyses by slow and fast coking gave:

Slow coking. Fast coking.

Analyses of.

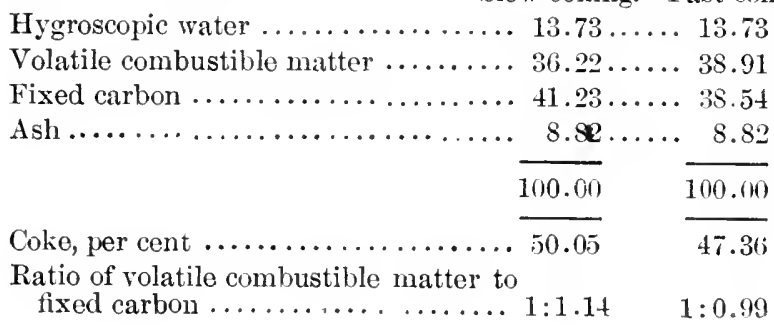


It yields-both by slow and fast eoking, a non-coherent coke; the gases evolved during coking burnt with a yellowish, slightly luminous, almost smokeless flame. The ash has a light brownishgrey color, it does not become agglutinated at a bright red heat, but at a most intense red heat it forms a slaggy mass.

Crignite from 4 froot Creek 41.-Lignite.-From a shaft sunk on the bank of Crowfoot Creek, about Bow River. fire miles from its entry into Bow River, section 7, township 22, range $\mathrm{xx}$, west of $4 \mathrm{th}$ principal meridian. Depth of shaft to bottom of coal, one hundred and thirty-five feet. Seam nine feet thick, with two shaly partings of twelve and three inches respectively. Geologieal position-Laramie.

[Speeimens Nos. 12 and 14 of the previous report-Report of Progress 1882-83-84, pp. 19-21 M.-are from natural exposures of the same seam, the former being about eight and the latter about six miles south of the shaft.]

Strueture somewhat fine lamellar-compact; it contains, interstratified, more or less disconnected, lenticular layers of dense, pitch-black, highly lustrous material, and an occasional layer of mineral chareoal; lustre sub-resinous to resinous; shows well defined planes of cleat; eolor greyish-blach to black, that of the powder, black, with a faint brownish tinge; it communicates a. deep brownish-red color to a boiling solution of caustic potash; apart from the layers of mineral chareoal, does not soil the fingers; by exposure to the air becomes slightly fissured, but is on the whole tolerably hard and firm. In appearance it resembles some varieties of coal of the Carboniferous system.

Analyses by slow and fast coking gave:

Slow coking. Fast coking.

\begin{tabular}{|c|c|}
\hline \multirow[t]{2}{*}{ 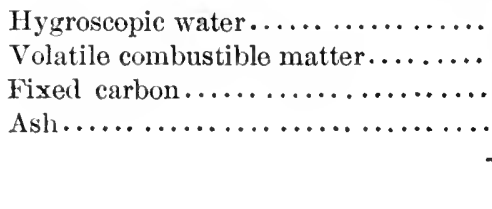 } & $\begin{array}{l}10.35 \\
30.97 \\
43.04 \\
15.64\end{array}$ \\
\hline & 100.00 \\
\hline 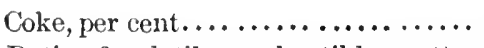 & 58.68 \\
\hline $\begin{array}{l}\text { Ratio of volatile combustible matter } \\
\text { to fixed carbon.................... }\end{array}$ & $1: 1.39$ \\
\hline
\end{tabular}

It yields-both by slow and fast coking, a non-coherent coke; the gases evolved during coking burnt with a yellow, luminous, slightly smoky flame. The ash has a very light brownish-grey color-exposed to a bright red heat it does not become agglutinated, at a most intense red heat it becomes slightly fritted. 
42.-Lignite._On branch of Willow Creek, six miles south-east of Lignite from head of mountain, Cypress Hills. Seam four feet thick. Geolo- Cypress Hills. gical position-Laramie. Collected by Mr. R. G. McConnell.

Structure fine lamellar-tolerably compact; it contains an occasional interstratified layer of mineral charcoal ; color black; lustre, sub-resinous to resinous; fracture uneven; powder black, with a faint brownish tinge; it communicates a deep brownish-red color to a boiling solution of caustic potash; by exposure to the air splits along the line of bedding and falls to picees.

Analysis by fast coking gave :

Analysis of.

Hygroscopic water.................... 16.37

Volatile combustible matter.............. 35.58

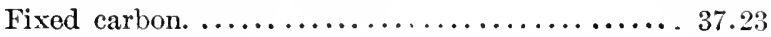

Ash ........................... 10.82

$\overline{100.00}$

Coke, per cent................... 48.05

Ratio of volatile combustible matter tofixed carbon 1:1.05

It yields a non-coherent coke; the gases evolved during coking burnt with a pale yellowish, feebly luminous, smokeless flame. The ash has a pale greenish-grey color-exposed to a bright red heat it does not agglutinate, but at a most intense red heat it fuses to a vitrified mass.

43.-Lignitic Coal_From the north edge of Milk River Ridge, one Lignitic coal and a-half mile east of Fossil Coulée. Seam eighteen inches thick, River Ridge. Southern extension of "Coal Bank's" main seam. Geological position_Cretaceous, base of Pierre. Collected by Dr. G. M. Dawson.

[This exposure of the Coal Banks main seam is thirty-three miles distant, in a south-southeasterly direction, from Coal Banks, whilst that on the St. Mary River is about ten miles south of Coal Banks-vide specimens Nos. 26 and 27 of former report, Report of Progress 1882-83-84, pp. 30-31 M. Specimen No. 26 was taken from the level (how far in from the entrance was not stated) commenced during the summer of 1882 at Sheran's mine, which is on the left bank of the river at Coal Banks, the Nortl-western Coal and Navigation Company's mine (Lethbridge mine), being on the opposite side of the river. Specimen No. 27, from the St. Mary River-thickness of the seam, at the point indicated, three feet eight inches.]

Structure somewhat fine lamellar, tolerably compact; color greyish-black, almost pure black; lustre resinous; intersected by 
Lignitic coal from llilk River Pidge, continued.

Analyse: of. numerous thin films of calcite and pyrite; does not soil the fingers; powder black with a brownish tinge; it communicates a brownish-red color to a boiling solution of canstic potash; does not readily become fissured when exposed to ths air, and may, on the whole, be said to be a fli'm coal.

Analyses by slow and fast coking gave:

Slow coking. Fast coking.

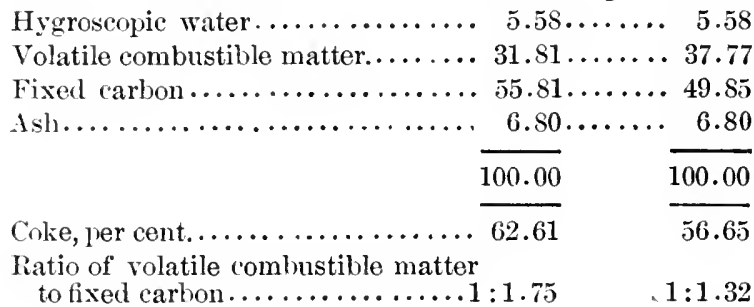

It yields-by slow coking, a non-coherent coke,-by fast coking a slightly fritted coke; the gases evolved during colking burnt with a yellow, luminous, somewhat smoky flame. The ash has a pale dirty reddish-brown color, - - exposed to a bright red heat it becomes slightly sintered, at a most intense red heat it forms a more or less slaggy mass.

Coal from Crow 44.-Coal-From Crow Nest Pass, Rocky Mountains. Middle seam. Nest Pass. Rocky Mumntains.

Seam two feet ten inches thick. Geological position-Cretaceous, Collected by Dr. G. M. Dawson.

Structure tine lamellar, the lines of bedding are, however, almost obliterated-compact; shows slickensides; color black; lnstre vitreous; hard and firm; fracture uneven; scarcely soils the fingers; powder almost black; it communicates a brownishycllow color to a boiling solution of caustic potash; resists exposure to the air'; in appearance it closely resembles some varieties of. coal of the Carboniferous system.

Analysis of. Inalysis by fast coking gave:

Hvgroscopic water.................... 1.82.

Volatile combustible matter. ............. 24.55.

Fixed carbon...................... 51.22

Ash.............................. 22.41

100.00

Coke, per cent...................... $\overline{73.63}$

Ratio of volatilo combustible matter to fixod carbon $1: 2.09$

It yiclds a compact, firm, colierent coke; the gases evolved during coling burnt with a yellow, luminous, smoky flame. Color 
of the ash, white, with a faint greyish tinge-exposed to a bright red heat it remains unaffected, at a most intense red heat it becomes slightly agglutinated.

45.-Coal.-From the Red Deer River, Rocky Mountains. Northern Coal from the continuation of Cascade River anthracite trough. Seam broken River, Rocky up where exposed, and the thickness uncertain, but at least several feet. Collected by Dr. G. M. Dawson.

Structure very fine lamellar, the lines of bedding are not unfrequently indistinct or almost obliterated-compact; color black, but not pure black; lustre resinous; hard and firm; fracture uneven; does not soil the fingers; powder almost black; it communicates a pale brownish-yellow color to a boiling solution of caustic potash; resists exposure to the air' in appearance it closely resembles some varieties of coal of the Carboniferons system.

Analysis by fast coking gave :

Analysis of.

Hygroscopic water................... $\$ 2.90$

Volatile combustible matter............. 29.26

Fixed carbon ....................... 62.95

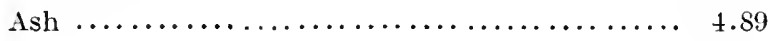

100.00

Coke, per cent........................ $\overline{67.84}$

Ratio of volatile combustible matter to fixed carbon $1: 2.15$

It yields a compact, firm, coherent coke; the gases evolved during coking burnt with a yellow, luminous, smoky flame. Color of the ash, white, with a faint reddish tinge-when exposed to a bright red heat it remains unaffected, at a most intense red heat it becomes just perceptibly fritted.

46. - Coal.-From the South Fork of the Old Man River, four miles Coal from the above the south branch, Rocky Mountains. Seam nine and three- Old Man River, quarters feet thick. Geological position-Cretaceons. Collected Rocky Mounby $D_{1}$. G. M. Dawson-and in such wise as to represent a fair average of the entire face of the seam.

Structure very fine lamellar, the lines of bedding, which are very numerous and close together, are not always very distinctcompact; color greyish-black; lustre sub-resinons to resinous; hard and firm; fracture uneven; slightly soils the fingers; powder almost black; it communicates a pale brownish-yellow color to a boiling solution of caustic potash; resists exposure to the air; in appearance it is not unlike some varietics of coal of the Carboniferous system. 
Coral from the Old Man River. South Fork,

Rocky Moun-

tains. Analysis of.

Coal from Oyster Creek, North Fork, old Man River.

Analysis of.

Coal from the Old Man River North Fork, Rocky Mountains.
Analysis by fast coking gave :

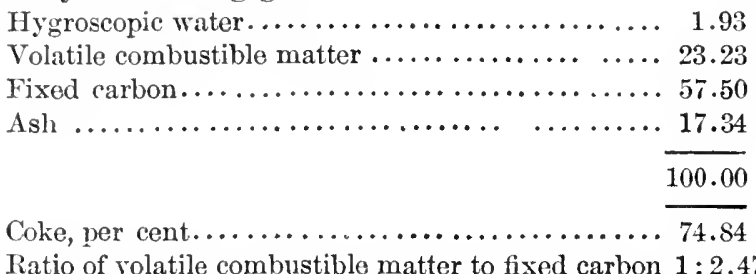

It yields a firm, coherent coke; the gases evolved during coking burnt with a yellow, luminous, somewhat smoky flame. Color of the ash, white-it does not show the least disposition to agglutinate even when exposed to a most intense red heat.

47.-Coal.-From Oyster Creek, north-west branch of the North Fork of the Old Man River. From one of numerous thin seams. Geologieal position-Laramie. Collected by Dr. G. M. Dawson.

Structure very fine lamellar, the lines of bedding, which are very numerous and close together, are almost obliterated-compact; color greyish-black; lustre sub-resinous to resinous; hard and firm; fracture uneven-it not unfrequently breaks into more or less rhombic fragments; does not soil the fingers; powder brownish-black; it communicates a very pale brownish-yellow color by a boiling solution of caustic potash; resists exposure to the air. The specimen in question was, in parts, very much soiled with argillaceous matter, and to this circumstance may be attributed the large percentage of incombustible matter which this sample of the fuel was found to contain.

Analysis by fast coking gave :

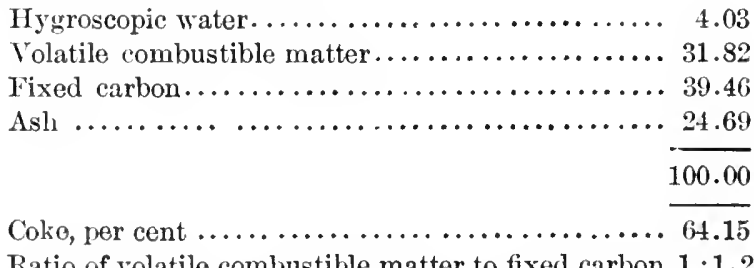

Ratio of volatile combustible matter to fixed carbon $1: 1.24$

It yields a firm, coherent coke; the gases evolved during coking burnt with a yellow, luminous, very smoky flame. Color of the ash, palo reddish-brown-exposed to a bright red heat it does not become agglutinated, at a most intense red heat it becomes fritted. 48.-Coal.-From north-west branch of the North Fork, Old Man River, Rocky Mountains. Seam eight feet (or more) thick. Geological position-Cretaceous. Collected by Dr. G. M. Dawson- 
and in such a manner as to represent a fair average of the entire face of the seam.

Compact; shows slickensides; color greyish-black; lustre subresinous to resinous; firm; fracture uneven; slightly soils the fingers; powder almost black; it communicates a very pale brownish-yellow color to a boiling solution of caustic potash; resists exposure to the air; in appearance it resembles some varieties of coal of the Carboniferous system.

Analysis by fast coking gave :

Hygrescopic water.................... 1.24

Analysis of.

Volatile combustible matter............... 24.62

Fixed carbon........................ 66.61

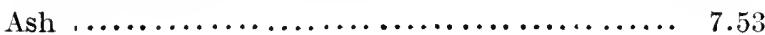

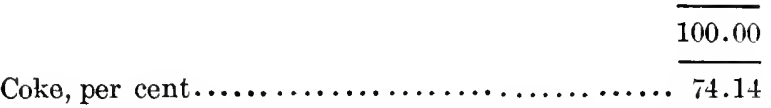

Ratio of volatile combustible matter to fixed carbon $1: 2.70$

It yields a firm coherent coke; the gases evolved during coking coal from burnt with a yellow, luminous, smoky flame. Color of the ash, Martin Creek, white-when exposed to a bright red heat it remains unaffected, tains. at a most intense red heat it becomes fritted.

49.-Coal--From second crossing, Martin Creek, Rocky Mountains, British Columbia. Seam about two feet thick. Geological position-Cretaceous. Collected by Dr. G. M. Dawson.

Structure very fine lamellar, the lines of bedding are not unfrequently very indistinct or altogether oblitcrated-compact; color black; lustre resinous; hard and firm; fracture uneven; does not soil the fingers; powder greyish-black; it communicates a very pale brownish-yellow color to a boiling solution of caustic potash; resists exposure to the air; in appearance it is not unlike some varieties of coal of the Carboniferous system. The sample received for examination was here and there coated with earthy matter which was not readily removable-this would account for the large percentage of incombustible matter which this particular specimen was found to leave on ignition.

Analysis by fast coking gave:

Hygroscopic water..................... 2.12

Volatile combustible matter............... 26.92

Fixed carbon........................ 43.48

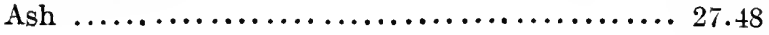

Coke, per cent ...................... 70.96

Ratio of volatile combustible matter to fixed carbon $1: 1.61$ 
Semi-anthrit cite from the Bow River. Rocky Mountains.

Analyzis of.

Semi-anthracite from the Caseade River. Roeky Mountains.
It yields a compact, very firm, coherent colie; the gases evolved during coking burnt with a yellow, luminous, very smoky flame. The ash has a very pale reddish-brown color-when exposed to a bright red heat it does not agglutinate, at a most intense red heat it becomes slightly sintered.

50.-Wemi-anthracite.-From the Bow River, right bank, about one and a-half mile from Canmore Station, Canadian Pacific Railway. Seam about one foot thick. Southern continuation of Cascade River anthracite trough. Colleeted by Dr. G. M. Dawson.

Structure lamellar, the lines of bedding are, however, not unfrequently very indistinct-compact; shows slickensides; it contains an occasional very thin layer of mineral charcoal; color black, in parts iridescent; lustre for the most part bright, that of some of the denser layers sub-metallic; brittle; fracture, on the whole, uneven, that of the more lustrous bands more or less conchoidal; powder black; it communicates only a just perceptible yellowish tinge to a boiling solution of eaustic potash; when suddenly heated it decrepitates somewhat.

Analysis by fast eoking gave:

Hygroscopic water..................... 1.60

Volatile combustible matter $\ldots \ldots \ldots \ldots \ldots \ldots \ldots .12 .23$

Fixed carbon ....................... 82.32

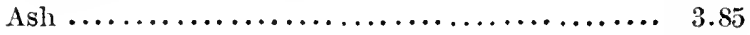

100.00

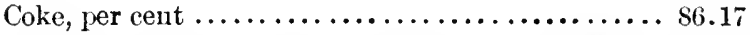

Ratio of volatile combustible matter to fixed carbon $1: 6.73$

It yields a non-coherent coke; the gases evolved during coking burnt with a yellowish, somewhat luminous, almost smokeless flame. Color of the ash,-reddish-white, exposed to a bright red heat it does not become agglutinated, at a most intense red heat it becomes slightly sintered.

51.-Semi-anthracite.-From Cascade River, near Bow River, about a quiter of a inile from the line of the Canadian Pacific Railway. Upper thick seam near Hughes' mine. Seam three feet ten inches thick. Geological position-Cretaceous. Collected by Dr. G. M. Dawson.

[The specimen of semi-anthracite, of which an analysis (No. 37) is given in the previous report, Report of Progress, 1882-83-84, p. 41 M., came from the Cascade mine (Moberly's), which is near Bantf Station, on the Canadian Pacifie Railway. The Hughes' mine, now Stewart's mine, above referred to, is about three miles distant from this mine.] 
Structure lamellar, made up of irregularly alternating layers of Semi-anthraa greyish-black, somewhat bright, and dense jet-black coal of cascade River, brilliant lustre-compact; in parts iridescent; brittle; fracture, tains, cont. on the whole, uneven, that of the denser and more lustrous layers, more or less conchoidal; powder black; it communicates only a just perceptible yellowish tinge to a boiling solution of caustic potash; hard and firm; resists exposure to the air; when suddenly heated it decrepitates, but not very considerably.

Analysis by fast coking gave:

Analysis of.

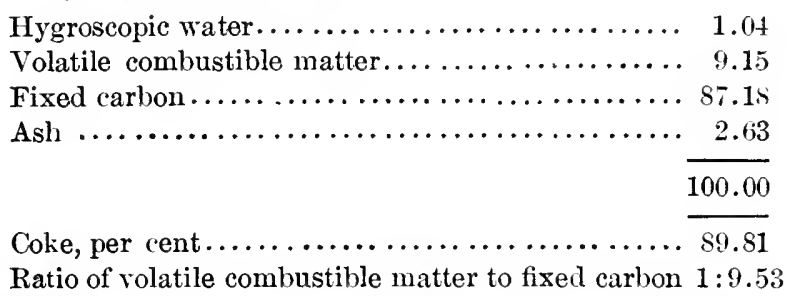

It yields a non-coherent coke; when heated in a corered crucible it yields a small amount of a pale yellow smokeless flame of feeble lnminosity. Color of the ash, white-it does not agglutinate at a bright red heat, and even at a most intense red heat becomes ouly very slightly fritted.

Of the foregoing, No. 41 may be regarded as a lignite of superior (ieneral quality; it is tolerably hard and firm, would, when freshly won, remaracter and bear transportation, and might be advantageously employed for of these fuels. domestic and other heating purposes. The same remarks apply to No. 43. Numbers 44 to 51 inclusive, are all good firm fuels, do not, apparently, break down on exposure to the weather, and might be expected to resist the friction incident to carriage, without serious waste by reduction to fine material. Numbers 44 to 49 inclusive, burn with a good flame, yield firm coherent cokes (even in the case of Nos. 44, 47, and 49, which contained an unusually large proportion of inorganic matter-the presence of which has been, in so far as numbers 47 and 49 are concerned, explained under their respective analyses) and are all good serviceable fuels, and well adapted for household purposes, for raising steam, and gas-making; numbers 47 and 49 in particular would, judging from the character of the flame of the gases evolved during coking, afford good material for the latter purpose. Numbers 50 and 51 differ materially from all the foregoing in chemical composition, the latter very closely resembles No. 37 of the previous report; it is an excellent fuel, and will no donbt, as in that instance, be 
found to possess a high evaporative power, and in consequence prove valuable for the generation of steam.

\section{NATURAL WATERS.}

Spring water from the seigniory of Longueuil.

Analysis of.
1.- Spring water from the seigniory of Longueuil, Soulanges. County, Province of Quebec. Examined for Mr. J. E. Juaire. The spring from which this water was taken is said to be situated about three-quarters of a mile from the village of River Beaudette. and forty feet from the bank of the Beaudette River.

It was described as filling a natural basin of sixty by forty feet, into which the water rises through some ten or twelve holes at the bottom, and from which the flow was estimated to be about four hundred and fifty gallons a minute. This spring rises from the Cambro-Silurian-Chazy.

The sample of this water sent for examination was perfectly clear and bright; quite colorless, even when viewed in a column two feet in length; was devoid of odor and any marked taste, either at the ordinary temperature or after having been warmed. The specific gravity at $15^{\circ} \cdot 5 \mathrm{C}$., was found to be $1000 \cdot 16$.

The preeipitate produced by boiling consisted of carbonate of lime and carbonate of magnesia with traces of ferric oxide. The amount of carbonic acid found is in excess of that required to form bi-carbonates.

Analysis gave as follows, for 1000 parts :

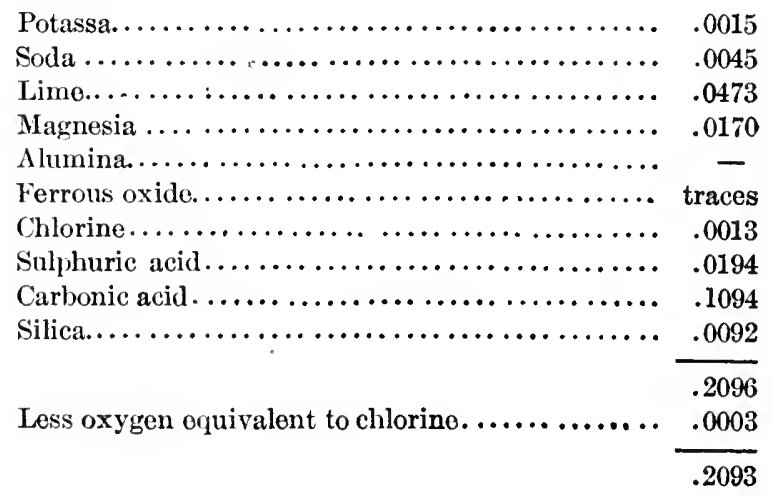


The foregoing acids and bases are most probably combined in Analysis of the water as follows:

(Carbonates being calculated as mono-carbonates, and all the salts esti- seigniory of mated as anhydrous.)

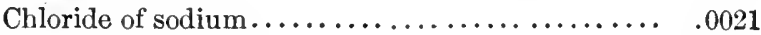

Sulphate of potassa ................... .0028

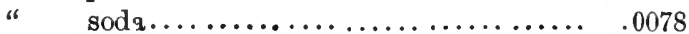

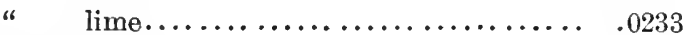

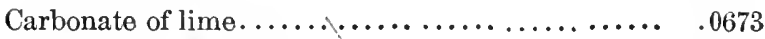

" magnesia .................... .0357

" iron $\ldots \ldots \ldots \ldots \ldots \ldots \ldots \ldots \ldots \ldots$ traces

Silica............................ .0092

.1482

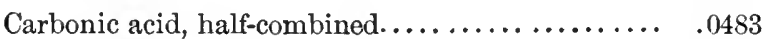

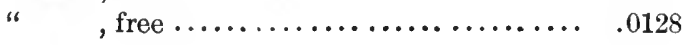

.2093

An Imperial gallon of this water would contain :

(Carbonates calculated as anhydrous bi-carbonates, and the salts without their water of crystallisation.)

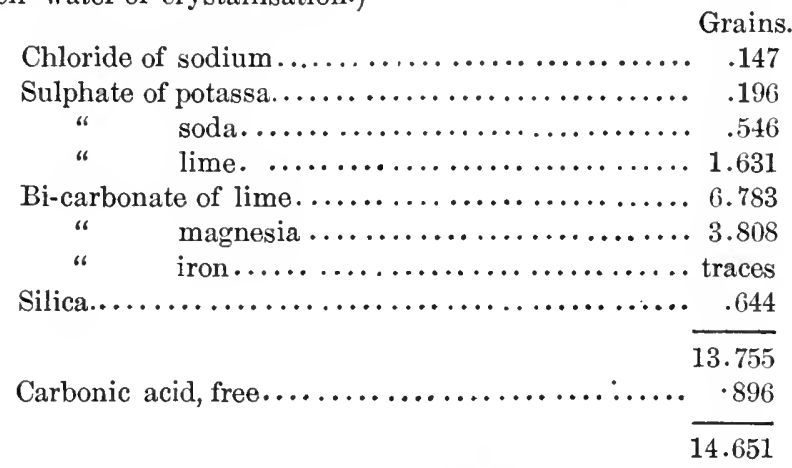

2.-Saline water from an artesian well at Rosenfeld Station, on the Salinewater, line of the Canadian Pacific Railway, Manitoba. The sample was $\begin{gathered}\text { Rosenfeld } \\ \text { Station }\end{gathered}$ obligingly procured and forwarded-April, 1885,-by J. M. Fgan, Manitoba. Esq., at the instance of Dr. G. M. Dawson. The latter gentleman informs me that the brine was first struck at a depth of two hundred and thirty-five feet, that the flow continued to increase as the boring progressed, rising to the surface and forming a strong flowing well.

The water, when received, contained a small quantity of reddish-brown colored suspended matter, which, for 1000 parts by weight of the brine, amounted to 0.0103 , and of this, 0.0067 consisted of ferric oxide, which latter had, doubtless, at one time been present in the water as ferrous carbonate. The filtered 
Saline water Rosenf eld Station. Manitoba continued.

Analysis of. water was perfectly colorless; taste, strongly saline with a very slightly bitter after taste; it did not affect the color of turmeric paper, but exhibited a slightly alkaline reaction with reddened litmus paper. The reaction for boric acid, although faint, was quite distinct. Bromine and iodine are both present-the amount of the former exceeding, apparently, that of the latter,-but owing to a total insufficiency of material, the determination of the respective amounts of these constituents, could not be carried out. The specific gravity of the water, at $15^{\circ} \cdot 5 \mathrm{C}$., was found to be $1032 \cdot 86$. Its analysis gave as follows, for 1000 parts by weight:-

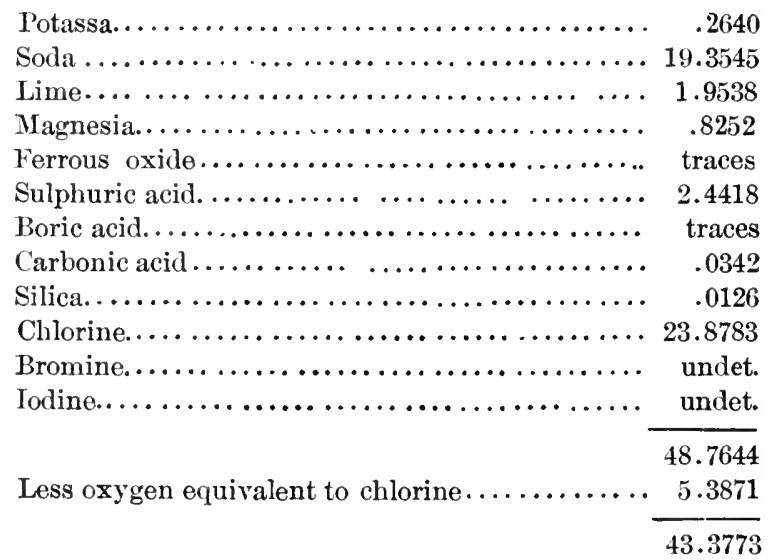

Less oxygen equivalent to bromine and iodine .. unascertained.

It may be reasonably assumed that the foregoing acids and bases exist in the water in the following state of combination :

(The carbonate being calculated as mono-carbonate, and all the salts estimated as anhydrous.)

Chloride of potassium .4179

66 sodium 36.4971

66 calcium

.3982

66

magnesium ................... 1.7225

Sulphate of lime....................... 4.1511

Borate of soda......................... traces

Carbonate of lime........................ .0777

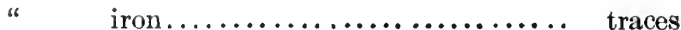

Bromide of magnesium.................... undet.

Iodide of magnesium...................... undet.

Silica.............................. .0126

The proportion of magnesium assumed to be present as bromide and iodide, amounts to 0.0596 . 
This water, in common with those of Hallowell, St. Catherines, Saline water, and Ancaster, belongs to the first class of Dr. T. Sterry Hunt's Station, classification of mineral water's (Geology of Canada, 1863, p. 531). continued. It almost equals in strength the strongest of these saline water's, -viz., one from Hallowell, which was found by Dr. T. S. Hunt to contain, in 1000 parts, 38.7315 of chloride of sodium,-and would be far superior to either of them for the manufacture of salt, in that it contains a very much smaller amount of the deliquescent chlorides of calcium and magnesium.

Water from a spring at Halowell Grant, about eight or nine miles Water from north of the town of Antigonish, Antigonish County Nova Scotia HolowellGrant, The sample was kindly procured and forwarded-October, 1884 by Henry P. Hill, Esq., of Antigonish. The spring in question rises from rocks which are most probably of Lower Carboniferous age.

Mr. Hugh Fletcher, at whose instance the sample in question was collected, informs me that this water is drunk for a valiety of ailments, and, as it is asserted, with beneficial results.

It was found to contain a very appreciable amount of suspended matter. This was removed by filtration. The filtered water, when viewed in a column two feet in length, was found to have a faint brownish tinge. It was inodorous and devoid of any special taste. The suspended matter of 1000 parts of the water contained an amount of iron corresponding to 0021 of ferric oxide, the same was, in all probability, at one time present in the water as ferrous carbonate. The specific gravity of the water at $15^{\circ} \cdot 5 \mathrm{C}$. was found to be $1000 \cdot 53$.

Agreeably with the results of an analysis conducted by $\mathrm{Mr}$. Analysis of. Frank D. Adams, the filtered water contained in 1000 parts :-

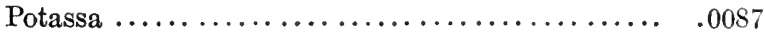

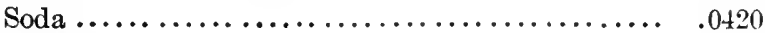

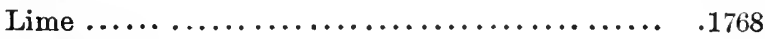

Magnesia ........................... .0141

Alumina. ........................... .0005

Ferrous oxide ........................ . 0015

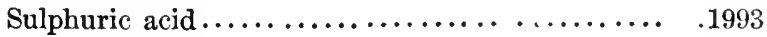

Phosphoric acid ..................... traces.

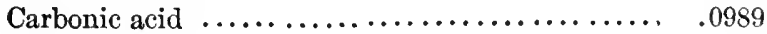

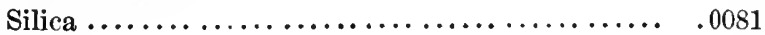

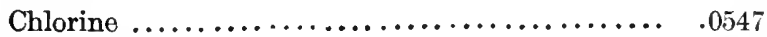

Organic matter ....................... traces.

Less oxygen equivalent to chlorine $\ldots \ldots \ldots \ldots \ldots . .0123$ 
Water from HalowellGrant, Nova Scotia. Analysis of, continued.
The foregoing acids and bases are most probably combined in the water as follows:-

(Carbonates calculated as mono-carbonates, and all the salts estimatec as anhydrous.)

Chloride of potassium................... .0137

" sodium $\ldots \ldots \ldots \ldots \ldots \ldots \ldots \ldots \ldots \ldots . . . \ldots 793$

Sulphate of lime...................... .3388

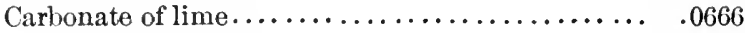

" magnesia.................... 0296

" $\quad$ iron $\ldots \ldots \ldots \ldots \ldots \ldots \ldots \ldots \ldots \ldots \ldots . . . \ldots 024$

Alumina ............................. .0005

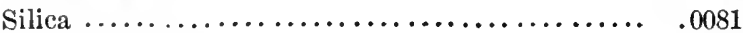

Phosphoric acid..$\ldots \ldots \ldots \ldots \ldots \ldots \ldots \ldots \ldots$ traces.

Organic matter ........................ traces.

Total dissolved solid matter, by direct experiment, dried at $180^{\circ} \mathrm{C} ., 0.5383$.

Carbonic acid, half-combined............... . .0457

" , free $\ldots \ldots \ldots \ldots \ldots \ldots \ldots \ldots \ldots . .0075$

.5922

Chlorine in excess of that required by the potassium

and sodium .0001

.5923

An Imperial gallon of the water would contain :-

(Carbonates calculated as anhydrous bi-carbonates, and the salts withou their water of crystallisation.)

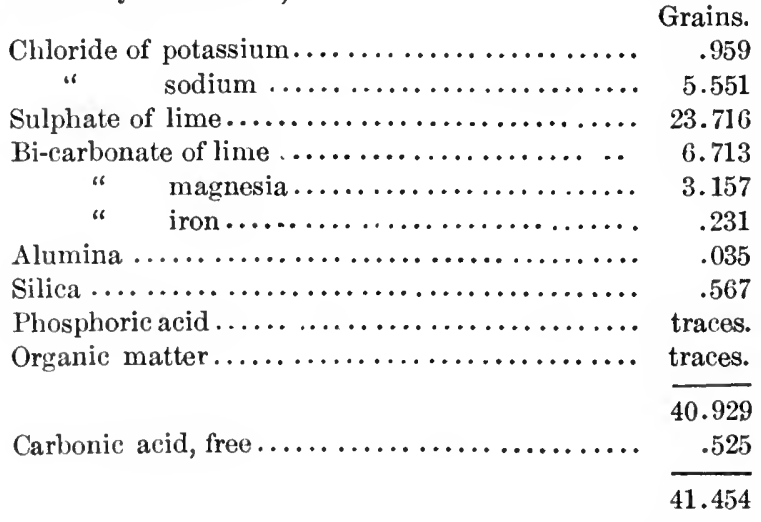

This water belongs to the sixth class of Dr. T. Sterry Hunt' classification of mineral waters. (Gcology of Canada, 1863, r 531.) 
1.-Water from Silver Islet mine, Lake Superior; Ontario. It was Water from collected by Capt. Trethewey at the instance of Dr. A. R. C. Mine, Lake Selwyn.

The islet_which lies at a distance of about half a mile from the north shore of the lake, and six miles east of Thunder Cape-consists of part of a dyke of diorite which cuts the nearly horizontal dark colored slates of the Animikie series. It is traversed by a vein consisting of calcite, dolomite, fluorite, and quartz. The silver occurs both native and as argentite. Other associated minerals are tetrahedrite, domeykite, galenite, sphalerite, pyrite, chalcopyrite, erythrite, and annabergite. The workings at the date of collection of the water, summer, 1882, had been carried to a depth of about eleven hundred feet.

The water contained some suspended matter which on examination was found to be, for the most part, of an argillaceous nature. This was removed by filtration. The filtered water was colorless and odorless; it tasted strongly saline, with a slightly bitter aftertaste; reaction, neutral. The specifie gravity of the water at $15^{\circ} \cdot 5 \mathrm{C}$. was $1028 \cdot 48$.

An analysis by Mr. Frank D. Adams showed it to contain-in Analysis of. 1000 parts by weight:-

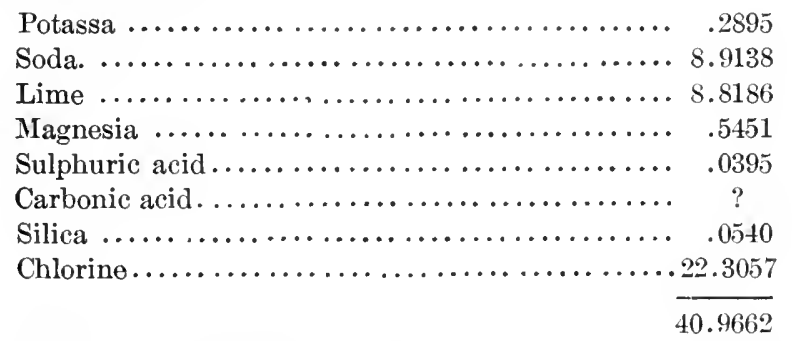

Less oxygen equivalent to chlorine ........... 5.0323

35.9339

Total dissolved solid matter, by direct experiment, dried at $180^{\circ} \mathrm{C}$., $35 \cdot 9566$.

The foregoing acids and bases are most probably combined in the water as follows:-

(Carbonates calculated as mono-carbonates, and all the salts estimated as anhydrous.)

Chloride of potassium . ................ .4582

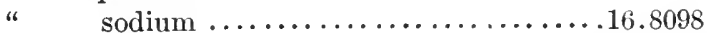

" calcium ......................17.0867

" $\quad$ magnesium.................... 1.2937

Sulphate of lime $\ldots \ldots \ldots \ldots \ldots \ldots \ldots \ldots \ldots \ldots . .0672$

Carbonate of lime..................... .2936

Silica .............................. . .05 . 
Water from

Silver Islet

Mine, Lake

Superior, cont.

Iron ores. Magnetite from 5.-Magnetic iron-ore found on the property of Mr. R. W. Bulkeley,
Digby, Nova

Scotia.

Partial analysis

Partial analysis
of.
The water was found to contain a trace of manganese and a minute trace of cobalt. Alumina and iron were absent. The quantity of the water at the disposal of the operator was too limited to admit of its being tested for bromine and iodine. There is an excess of 0.1644 lime; this might, not improbably, be present as carbonate-it has been thus represented above.

'This water belongs to the first class of Dr. T. Sterry Hunt's classification of mineral waters (Geology of Canada, 1863, p. 531.)

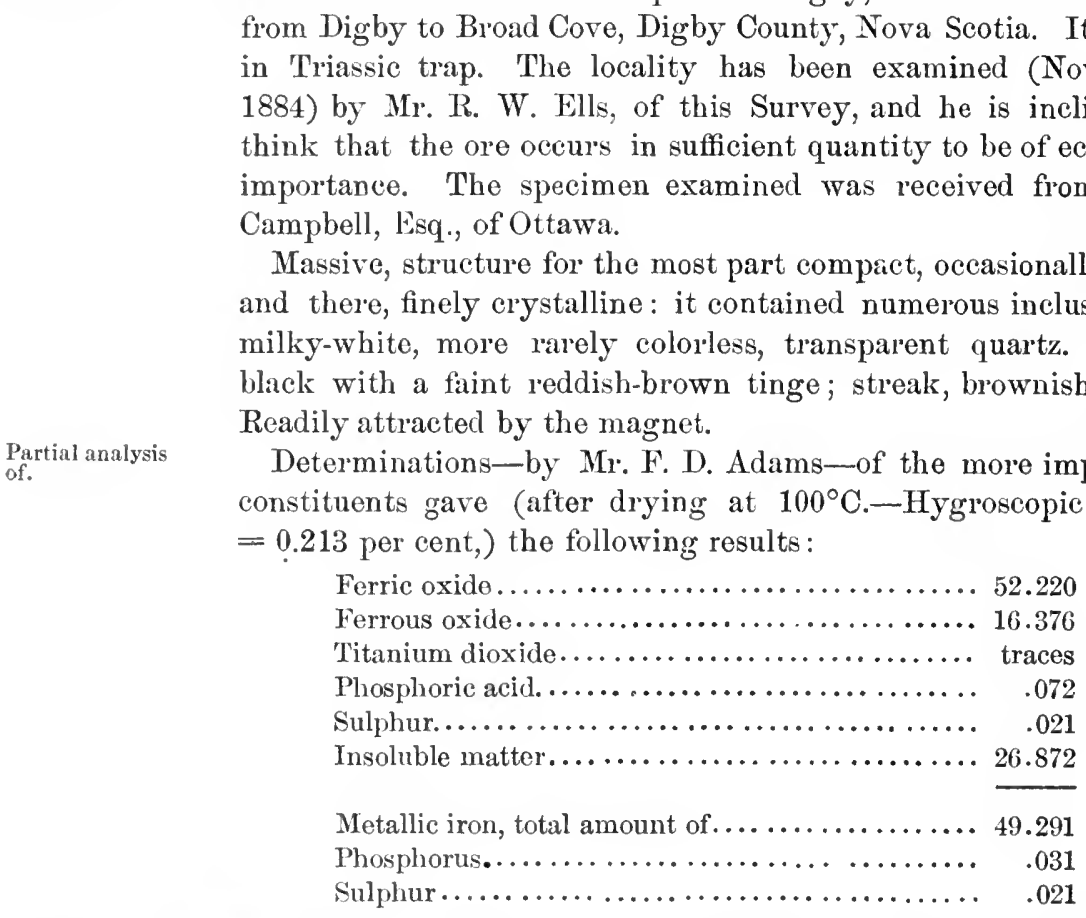

Magnetite from 6.-Magnetic iron-ole from the thirteenth lot of the tenth range of Bagot, Ontario. Bagot, County of Renfrew, Ontario. The specimens here referred to were rcceived from C. F. Gildersleeve, Esq., of Kingston. The one first sent consisted of a single fragment, weighing one pound six ounces, and answered to the following description :

Massive, structure fine-granular-minute octahedral crystals of magnetite, more or lesa isolatcd or in small aggregations, occur 
scattered through the mass. Color, dark steel-grey. Streak, red-Magnetite from dish-brown. Readily attracted by the magnet. It consisted, continued. apparently, of a mixture of crystalline magnetite and hematite.

This was subsequently replaced by another sample which was in the form of moderately coarse powder and stated to consist of material taken from various parts of the exposure. As an analysis of this was deemed more likely to convey some idea of the general quality of the ore than that of one of the preceding specimen, it was the one selected for examination. It was strongly magnetic and afforded a black streak.

A partial analysis-by Mr. F. D. Adams-showed it to contain partial analysis (after drying at $100^{\circ} \mathrm{C}$ - - Hygroscopic water $=0.104$ per cent.) as of. follows:

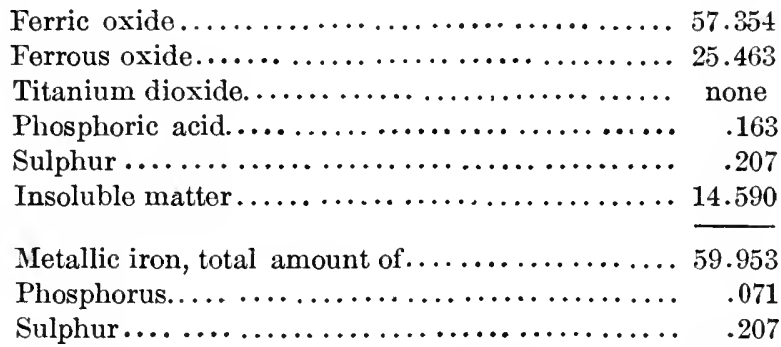

The ratio of ferric oxide to ferrous oxide in this sample of the ore, is almost identical with that required by theory for magnetite. The insoluble matter consisted, for the most part at least, of the variety of hornblende known as actinolite.

\section{COPPER ORES.}

7.-From the eleventh lot of the fifth concession of the township of Copper-pyrites McKim, District of Nipissing, Ontario: Collected by Dr. A. R. C. Distriot of Selwyn.

The sample was taken from an exposure in a cutting on the line of the Canadian Pacific Railway, at which place the ore-bearing rock or vein was found to have a width of forty yards: it is reported that the vein has been traced for a considerable distance on both sides of the track. It consisted of magnetic-pyrites and copper-pyrites, in association with a dark-grey fine-grained diorite and a greyish-green chloritic schist; a few of the fragments were, in parts, coated with hydrated peroxide of iron. Some specimens of the magnetic-pyrites from this deposit contained numerous flakes of molybdenite; this mineral was not, however, observable in any of the fragments composing the sample under consideration. 
Partial

analysis of.

Manganese

ores.

Psilomelane from Albert County, New Brunswiek.

Partial analysis of.

Gold and silver assays.
It was found to contain :-

After (lrying at $100^{\circ}$ C., (Hygroscopic water $=0.085$ per cent.)

The above 9.08 copper requires, theoretically, 8.02 of iron and 9.17 of sulphur, therewith forming 26.27 copper-pyrites, the balance of the sulphur 9.52 may, for all practical purposes, be regarded as present in the form of magnetic-pyrites.

This ore was also assayed for gold and silver and with the results stated under Gold and Silver Assays, Assay No. 5.

8.--From Gowland Mountain, Elgin, Alber't County, New Brunswick. Forwarded to the Survey by Mr. J. L. Harris.

This specimen consisted of psilomelane in association with a trifling amount of pyrolusite; it contained numerous small angular fragments of a reddish or greyish crypto-crystalline quartzite, much of the ore in consequence assuming the character of a well defined breccia. The specimen, which was made up of numerous fragments, weighed a little over thirty-seven and a-half pounds; the whole of this was reduced to coarse powder and a fair average sample prepared from the same. A partial analysis afforded Mr. F. D. Adams the following results:

After drying at $100^{\circ} \mathrm{C}$., (Hygroseopic water $=0.855$ per cent.)

Manganese dioxide-available........ 50.21 per cent.

Ferric oxide.................... 3.06 "

Insoluble residue..................

Agreeably with the results of a qualitative examination, this ore would appear to contain a very appreciable percentage of baryta.

GOLD AND SILVER ASSAYS.

Province of New Brunswick.

Provinee of 1 . The following specimen was examined for G. G. King, Esq., it was not labelled, so that the exact locality is not known-it is presumably from Queen's County. 
A white translucent quartz, associated with a small quantity of Gold and silver a dark-grey, almost black shale,-carrying a little iron-pyrites : it was in parts coated with ferric hydrate.

It contained neither gold nor silver.

Province of Ontario.

Assays Nos. 6 to 13 inc. were conducted by Mr. F. D. Adams.

2.-From the township of Artemisia, Grey County. Examined for T. Province of S. Sproule, Esq.

It consisted of a white translucent quartz carrying iron pyrites, the latter constituted, approximately, two-thirds, by weight, of the whole. Weight of specimen, rather more than one ounce. It was found to contain:

Gold.......... None.

Silver....... 0.364 of an ounce to the ton of $2,000 \mathrm{lbs}$.

3.-Specimen of band in centre of vein, Huronian mine, Jackfish Lake, township of Moss, District of Thunder Bay, Lake Superior.

An olive green chloritic schist carrying iron-pyrites, in association with a white translucent quartz. Weight of sample thirteen ounces.

It contained neither gold nor silver.

4.-From location R. 71, Osinawe Lake, west of Partridge Lake, and west-north-west of Thunder Bay, Lake Superior. Received from W. A. Allan, Esq.

The specimen, which was stated to be a fair average of a large bulk of the ore, was made up of numerous small fragments: these consisted for the most part of a milky-white quartz, in parts stained with ferric hydrate, carrying a little galena and ironpyrites; other fragments consisted of a translucent quartz traversed by numerous fissures filled with ferric hydrate, imparting to the whole a flesh-red color; these fragments also carried a little iron-pyrites. Assays showed it to contain :

Gold.........2.042 ounces to the ton of $2,000 \mathrm{lbs}$.

Silver......... 1.22

5.-From lot eleven, concession five of the township of McKim, District of Nipissing.

This specimen has been described under Copper Ores, Analysis 8. It was found to contain :

Gold.......... mere traces.

Silver....... 2.187 ounces to the ton of $2,000 \mathrm{lbs}$. 
Gold and silver 6.-This, and the following seven specimens, were collected by Mr. E. assays, cont D. Ingall.

Iron-pyrites taken from a three feet vein of quartz, Cape Victoria, Lake Superior.

The pyrites, which was fine to coarse crystalline, separated from associated gangue, was found to contain:

Gold .......... 0.117 of an ounce to the ton of $2,000 \mathrm{lbs}$.

Silver......... 7.455 ounces

7.-Taken from a quartz band, northern end of Jackfish Bay, Lake Superior.

Finely crystalline iron-pyrites associated with a little copperpyrites and chlorite. It contained :

Gold........... none.

Silver........ 0.350 of an ounce to the ton of $2,000 \mathrm{lbs}$.

8.-From an island in Terrace Bay, Lake Superior. Taken from quartz stringers said to carry a considerable proportion of this mineral.

A coarsely crystalline iron-pyrites. Assays gave:-

Gold......... mere traces.

Silver....... 0.204 of an ounce to the ton of $2,000 \mathrm{lbs}$.

9.-From Heron Bay, Lake Superior.

A rudely banded mixture of greyish translucent quartz, reddish colored felspar, finely crystalline iron-pyrites, and a small quantity of a chloritic mineral.

It contained neither gold nor silver.

10.-From a vein two to six inches thick at Still River, Lake Superior.

A fine crystalline iron-pyrites.

It contained neither gold nor silver.

11.-From Jackfish Bay, north shore of Lake Superior.

An association, in about equal proportions, of greyish translucent quartz and a reddish colored felspar. It contained a trifiing amount of finely disseminated iron-pyrites. Assays gave:

Gold....... distinct traces. Silver...... none.

12.-From a location near Lac des Milles Lacs, District of Algoma.

An association of a finely crystalline iron-pyrites and a bluish ferruginous magnesite.

It contained neither gold nor silver. 
13. -Taken from a one foot quartz vein, vicinity of Sault Ste. Marie, Gold and silver District of Algoma.

A fine grained mixture of iron-pyrites and greyish translucent $\begin{gathered}\text { Province of } \\ \text { Ontao, cont. }\end{gathered}$ quartz. Assays showed it to contain :

Gold.......... trace.

Silver....... 0.292 of an ounce to the ton of $2,000 \mathrm{lbs}$.

14.-From the Arctic mine, Black Bay, Lake Superior.

A moderately fine erystalline galena-through which was disseminated a little iron-pyrites-in a gangue of quartz, intermixed with which was a trifling amount of a ferruginous dolomite. Weight of specimen, nine and three-quarter ounces. It was found to contain :

Silver............................ traces.

15.-From Current River, north-west corner of location B, township of McIntyre, Thunder Bay, Lake Superior. Received from J. Dewé; Esq.

Zinc-blende in a gangue consisting of a coarse erystalline calcite, a light grey shale and a little quart\%. Weight of specimen, two pounds one ounce. It contained:

Silver....... 0.073 of an ounce to the ton of $2,000 \mathrm{lbs}$.

North-West Territory.

16.-From Ghost River, about fifty miles west of Calgary.

A dark, faintly purplish, grey colored limestone, carrying a large amount of iron-pyrites. Weight of specimen, thirteen ounces. Assays showed it to contain:

Gold.......... traces.

Silver........ 0.729 ounce to the ton of $2,000 \mathrm{lbs}$.

17.-From Bow River, Rocky Mountains. Received from Mrr. Olef Johnson.

Copper-glance, in parts coated with green carbonate of copper, associated with a small quantity of calcite and quartz. Weight of specimen, six and a-half ounces. It was found to contain:

Gold........... traces.

Silver........ 9.989 ounces to the ton of $2,000 \mathrm{lbs}$.

18.-From "Storm" or "Copper" Mountain, Rocky Mountains, western part of the district of Alberta. Collected by Dr. G. M. Dawson.

A gossan. Weight of specimen, six and three-quarter ounces. It contained neither gold nor silver. 
Gold and silver assays, cont.

Province of British Columbia.

\section{Province of British Columbia.}

19.- This and the three following specimens are from Tunnel Mountain, nine miles west of summit of Rocky Mountains. They were taken from different parts of what was stated to be an exiensive deposit. Received from Mr. T. S. Higginson.

This specimen consisted of an exceedingly fine granular galena. It was found to contain :-

Gold ........... Traces.

Silver....... 3.996 ounces to the ton of $2,000 \mathrm{lbs}$.

20.-A fine to moderately coarse crystalline galena, through which was disseminated a trifling amount of copper-pyrites; it did not contain any readily discernable gangue. Weight of specimen, ten ounces. Assays gave :-

Gold.......... Traces.

Silver........ 4.010 ounces to the ton of $2,000 \mathrm{lbs}$.

21.-A coarsely crystalline galena, associated with a little copperpyrites, in a gangue of quartz and calcite-in parts coated with ferric hydrate, and here and there stained with blue and green carbonate of copper; the gangue constituted but a very small proportion, by weight, of the whole. Weight of specimen, five ounces. It contained :-

Gold.......... Traces.

Silver....... 11.302 ounces to the ton of $2,000 \mathrm{lbs}$.

22.-A fine to coarse crystalline galena, associated with a small quantity of iron pyrites; it contained but a very trifling amount of gangue. Weight of specimen, one pound seven ounces. Assays showed it to contain :-

Gold........... Traces.

Silver........ 3.281 ounces to the ton of $2,000 \mathrm{lbs}$.

23.-From Otter Tail Creek, thirty-eight miles west of summit of Rocky Mountains, and one mile south of the traek of the Canadian Pacific Railway. 'This and the four following specimens were received from Mr. T. S. Higginson.

A white translucent quartz in association with ealcite, earrying a coarsely erystalline galena and a little copper pyrites; it was in parts coated with ferrie hydrate. The metallic sulphides constituted, approximately, forty per cent., by weight, of the whole. The sample, which was made up of numerous fragments, weighed 
two pounds seven ounces. A fair average of the whole was found Gold and silver to contain :-

Gold.......... Traces.

Silver........ 3.281 ounces to the ton of $2,000 \mathrm{lbs}$.

24.-From the same locality as the preceding specimen.

It consisted of an association of a coarse crystalline galena and copper-pyrites, in a gangue of white translucent quartz with a little calcite; it was in parts coated with green carbonate of copper and ferric hydrate. The metallic sulphides constituted, approximately, seventy-five per cent., by weight, of the whole. Weight of the specimen, two pounds fifteen ounces. It contained :-

Gold.......... Traces.

Silver....... 5.833 cunces to the ton of $2,000 \mathrm{lbs}$.

25.-Also from the same locality as No. 23.

It consisted of copper pyrites in a gangue of white translucent quartz; it was in parts coated with green carbonate of copper and ferric hydrate. The metallic sulphides constituted, approximately, thirty-nine per cent., by weight, of the whole. Assays gave :-

Gold.......... Traces.

Silver........ 0.171 of an ounce to the ton of $2,000 \mathrm{lbs}$.

26.-From a mountain on the Kicking Horse River, on the line of the Canadian Pacific Railway, forty-nine miles west of the summit of the Rocky Mountains.

A ferruginous dolomite in association with small quantities of a white translucent quartz, and a pale apple-green talcose mineral, and a little calcite; it contained a few specks of iron pyrites, and was in parts coated with ferric hydrate; the whole presented a more or less weathered appearance. Weight of sample, which consisted of numerous fragments, one pound two ounces.

It contained neither gold nor silver.

27.-From Fifteen Mile Creek, Selkirk Mountains.

A white translucent quartz, carrying small quantities of copper pyrites and a trifling amount of a mineral which, in appearance, much resembled tetrahedrite (but which was not identified, as it was considered that the abstraction of a sufficient amount of the material to enable this to be done might not improbably injure the specimen for assay); the whole was more or less seamed and 
fold and silver assays, cont.

Province of British

Columbia. cont. coated with blue and green carbonate of copper and ferric hydrate. Weight of specimen, one ounce. Assays showed it to contain :Gold........... Traces.

Silver........ 2.552 ounces to the ton of $2,000 \mathrm{lbs}$.

28. -From the "International" claim, west side of Kootanie Lake.

A somewhat coarse crystalline galena, associated with a trifling amount of quartz. Weight of specimen, three-quarters of an ounce. This and the five following specimens were received from Mr. Fernie. It was found to contain :-

Gold .......... Traces.

Silver........ 10.719 ounces to the ton of $2,000 \mathrm{lbs}$.

29._-From Bull River, above the bridge. Reported as occurring in large quantity.

A massive, very fine granular haematite, seamed throughout with blue, and occasionally a little green carbonate of copper. Weight of specimen, four and a-half ounces.

It contained neither gold nor silver.

30._From the "Blue Bell" claim, east side of Kootanie Lake.

The specimen, which weighed one and three-quarter ounces, consisted of an intimate association of iron-pyrites and ferric hydrate, in parts incrusted with an efflorescence of ferrous sulphate, which latter was present in very notable quantity. The pyrites constituted, approximately, two-thirds, by weight, of the whole. Assays gave:-

Gold........... Traces.

Silver........ 1.823 ounces to the ton of $2,000 \mathrm{lbs}$.

31. From the "Lu-lu" mine, west side of Kootanie Lake.

A coarse crystalline galena; it did not contain any readily discernable gangue. Weight of specimen, five ounces. Assays showed it to contain :-

Gold.......... Traces.

Silver........ 15.458 ounces to the ton of $2,000 \mathrm{lbs}$.

32.-From mountains near Lower Columbia Lakc.

Consisted of chalcocite, seamed and coated with green and blue carbonate of copper; it contained but a very trifling amount of gangue, consisting of quartz. Weight of specimen, three ounces.

It contained neither gold nor silver. 
33.-From the Spilimichine River, Purcell Range.

A fine crystalline galena, through which was disseminated a Province of small quantity of iron-pyrites: it contained a very trifling amount ${ }_{\text {Columbia, cont. }}^{\text {British }}$ of gangue, consisting of quartz and a ferruginous dolomite. Weight of specimen, eight and a-quarter ounces. It contained :-

Gold........... Traces.

Silver........ 8.094 ounces to the ton of $2,000 \mathrm{lbs}$.

34.-From the Briscoe Range, Rocky Mountains, opposite lower end of Upper Columbia Lake. Received from Mr. D. Griffith. Reported as occurring in large quantity.

It consisted of chalcocite and bornite, with some blue and green carbonate of copper and a little copper-pyrites, in association with a colorless sub-transparent to transparent quartz. The gangue constituted but a small proportion, by weight, of the whole. Weight of specimen, one pound seven ounces.

It contained neither gold nor silver.

35.-From Nashwaak River, near Rocky Brook.

A milky white quartz, in parts stained with ferric hydrate; some of the fragments were thickly coated with this latter. Weight of specimen, one pound one and a-half ounce.

It contained neither gold nor silver.

36.--From Cross River, White Man's Pass, Rocky Mountains. Collected by Dr. G. M. Dawson.

A white translucent quartz, carrying a littlo copper-pyrites; it was in parts stained with green carbonate of copper and ferric hydrate. Weight of specimen, thirteen and three-quarter ounces.

It contained neither gold nor silver.

37.-From the Snow-flake vein, Columbia River. Received from Mr. W. Grier.

A milky white quartz, with numerous carities and seams filled with ferric hydrate, and here and there a few specks of ironpyrites. Weight of specimen, two and a-quarter ounces.

It contained neither gold nor silver.

38.-From Cross River, near Upper Forks. Collected by Dr. G. M. Dawson.

A white, somewhat coarsely crystalline dolomite, in parts stained and coated with hydrated peroxide of iron. Weight of specimen, four and a-quarter ounces.

It contained neither gold nor silver. 
Gold and silver 39.-From Beaver Creek, Columbia River. Received from Mr. T. S. assays, cont. Higginson.

A white translucent quartz associated with a small quantity of a greyish hydrous mica; the greater number of the fragments were thickly coated with hydrated peroxide of iron. Weight of specimen, three pounds two ounces.

It contained neither gold nor silver

40.-From the "Queen Mine," Yale Creek, two miles north of the town of Yale. Taken from the surface, at mouth of tunnel.

The material examined consisted of picked specimens taken from a sample, weighing thirteen pounds, of the ore forwarded for exhibition. Some fragments eonsisted of white translucent quartz carrying iron-pyrites, galena and a little zinc-blende, - others consisted of a greyish, somewhat fine granular quartz, in connection with a greyish-green to bright green chromiferous serpentine and, more immediately associated with the latter, some graphite; the whole contained a good deal of finely disseminated iron-pyrites. Assays showed it to contain:

Gold........... traces.

Silver....... 0.292 of an ounce to the ton of 2,000 lbs.

41.-Also from the "Queen Mine," Yale Creek. Taken one hundred and eighty feet in from mouth of tunnel.

The material examined consisted of picked specimens taken from a sample, weighing forty-eight pounds, of the ore forwarded for exhibitfon. It consisted of an association of zinc-blende and iron-pyrites, with a small quantity of white translucent quartz and a trifling amount of a greyish-white talcose mineral. The specimen assayed contained but very little gangue. Assays gave:

Gold.......... traces.

Silver.......2. 2.800 ounces to the ton of $2,000 \mathrm{lbs}$.

42.-From Fifteen Mile Creek, about six miles from its entry into the Columbia River, Selkirk Mountains.

A milky-white quartz thickly coated with ferric hydrate. Weight of specimen, thirteen ounces. This and the two following specimens were received from and examined for Mr. T. S. Higginson.

It contained neither gold nor silver.

43.-From ten miles west of summit of Selkirk Range, and about one and a-half mile from the line of the Canadian Pacific Railway.

A coarsely crystalline galena, associated with a trifling amount 
of copper-pyrites and calcite. This specimen-a very small one, Gold and silver weighing only one ounce,-was found to contain :

Gold .......... distinct traces.

Silver....... 79.956 ounces to the ton of $2,000 \mathrm{lbs}$.

\section{Province of} British

Columbia, cont.

44.-From Spilimichine Creek, Columbia River.

A very fine granular galena. It contained but a trifling amount of gangue. Weight of specimen, one pound two ounces. Assays showed it to contain :

Gold.......... traces.

Silver....... 4.667 ounces to the ton of $2,000 \mathrm{lbs}$.

\section{MISCELLANEOUS MINERALS.}

Miscellaneous minerals.

1.-Galenite.-From the Silver Islet mine, Lake Superior, Ontario.

The specimen in question-which was presented to $\mathrm{Mr}$. E. D. Galenite from Ingall by Mr. R. Trethewey, jun., as a clonation to the Museum of Mine, Lake the Survey, - was taken from a vug in the five hundred and sixty foot level, south of the main shaft. It was an aggregation of more or less perfect octahedra, the axes of some of which were five centimetres in length. A portion of one of the crystals was, as a matter of interest, assayed for silver, and found to contain 0.011 per cent. of that metal. Mr. Trethewey states that sometimes as much as a thousand pounds of galena, in the form just referred to, has been taken out of one of these crevices or vugs, and that these have been met with, from time to time, in nearly every level in the mine.

2.-Witherite.-From the Twin City mine, near Rabbit Mountain, Witherite from Thunder Bay, Lake Superior. Collected by Mr. E. D. Ingall of Mine, Thunder this Survey. He informs me that it occurs in a silver-bearing Bay, Lake vein, consisting, for the most part, of calcite and quartz, wlth some fluorite,-the silver occurs both native and as argentite. The specimen was in the form of radiating crystalline globular concre- tions-one fragment exceeded a pound in weight. The examination was conducted by Mr. F. D. Adams.

So far as I am aware, this is the first time that this mineral has been met with in Canada.

3.-Molybdenite.-Some well crystallized specimens of this mineral, Molybdenite from lots one and two of the third range of Aldfield, Pontiac County, Prom Aldfield, have been presented to the Museum of the Survey by Mr. R. H. G. P. Que.

Chapman. Some of the less perfect were of considerable dimensions, one measured about eleven centimetres across, and weighed close upon two and a-half pounds-of the smaller, an almost perfect and very handsome crystal, and which was in the form of a tubular hexagonal prism, measured very nearly five centimetres across. 


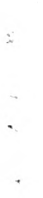




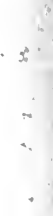




$$
\begin{aligned}
& \text { TP Canada. Geolonical Surve } \\
& 325 \text { Chemical contributions } \\
& \text { C3N173 } \\
& 1885
\end{aligned}
$$

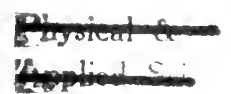

E" INEERING

PLEASE DO NOT REMOVE CARDS OR SLIPS FROM THIS POCKET

UNIVERSITY OF TORONTO LIBRARY 


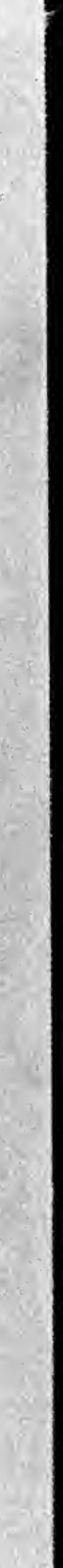

